Article

\title{
Consumers' Preference and Factors Influencing Offal Consumption in Amathole District Eastern Cape, South Africa
}

\author{
Babatunde Oluwasegun Alao ${ }^{1, * \mathbb{D}}$, Andrew Bamidele Falowo ${ }^{1}$, Amanda Chulayo ${ }^{2}$ \\ and Voster Muchenje ${ }^{1}$ \\ 1 Department of Livestock and Pasture Science, University of Fort Hare, Private Bag X1314, \\ Alice 5700, South Africa; anddele2013@gmail.com (A.B.F.); vmuchenje@ufh.ac.za (V.M.) \\ 2 Dohne Agricultural Development Institute, Department of Rural Development and Agrarian Reform, \\ Private Bag X15, Stutterheim 4935, South Africa; mkhuluwam@gmail.com \\ * Correspondence: alaoboo@hotmail.com; Tel.: +27-833-46-4435 \& +234-802-862-8544
}

Received: 21 August 2018; Accepted: 14 September 2018; Published: 17 September 2018

\begin{abstract}
This study was conducted to determine the consumers' perceptions and factors influencing offal meat consumption in Amathole District in the Eastern Cape Province of South Africa. A total of 202 consumers from Amathole District were randomly sampled from three municipalities. The study revealed that consumers were more influenced by the freshness, price, and availability of the product and these factors determine the point of purchase. The most preferred purchase-point for offal meat in this study was butchery. However, sheep offal was more preferred to cattle offal. The point of purchase, however, remains a prominent factor among other factors that could influence decision making for any consumer. When it comes to offal meat, the results showed that the majority of consumers purchased more liver, intestine, and tripe, which is because they are often sold in a combo at the butchery. Furthermore, it was revealed that consumers have nutritional knowledge of the offal meat products before making their purchase but health reasons emerged as a factor that the consumers considered the least at the point of purchase.
\end{abstract}

Keywords: offal; consumers; perception; consumption; meat quality; purchase-point

\section{Introduction}

About three decades ago, normal markets for offal meat progressively declined due to the outbreak of Bovine Spongiform Encephalopathy (BSE) otherwise called mad cow disease. The exclusion of offal meat for human consumption in the food chain was done to protect the public from the spread of BSE disease [1,2]. Although the re-occurrence of the reported outbreak or spread of the BSE disease declined in a remarkable manner after the exclusion of offal from the human diet and animal feed [1]. Consequently, purchase of offal meat decreased in regions that were affected because of the undesirable brand image of the by-product and was strongly constrained into pet food products [3].

Presently, offal meat is now seen as an excellent source of protein for several people across the continents and are now considered as delicacies used as basic traditional dishes. This is due to its potential to combat protein malnutrition and food insecurity in many countries [4]. In this regard, offal meat has been re-incorporated as constituents of traditional diets in many countries. At times, offal meat may be utilized on regular basis in a low-cost approach, as in pastries (for example, steak pie, pepper steak pie, and steak and kidney pie), to get high-quality protein and nutrition. In South Africa, carcass meat may be preferred but abattoir managers would have preferred that an animal produce twice or more offal than what they get presently. This is due to the increase in demand for offal meat consumption and the inability to keep up with such demand. Presently, meat and offal meat are a 
vital piece in the human diet as a result of the nutritional benefits obtained from these products [5]. The nutritional benefits enjoyed by society cannot be over emphasized. However, meat and offal meat has proven to be an excellent source of protein, fats, vitamins, and minerals that resourcefully enhance outstanding performance in human body systems [6].

Grunert et al. [7] in their study reported that consumers' perception of various products are influenced by attitudes and belief. Beliefs play a key role in the acceptance or rejection of a product because it could change the perception and image of that product [8]. Therefore, perception is defined as the method where consumers select, organize, and interpret information for immediate decision making [9]. Consumers usually form their feelings about the expected quality for meat while at the point of purchase [10]. "The decision to buy and eat meat is a direct outcome of how meat is perceived by the consumer" [11]. This is directly related to quality cue, which could be better explained as informational stimuli accessible by the consumer prior to purchase [12,13]. Quality cues are prerequisite required for consumers to evaluate displayed products and make a final decision at the point of purchase [14]. On the other hand, "perceived cues" are expected or experienced attributes of the offal meat that forms consumers approach towards the product. Previous experience plays a pivotal role in consumers' judgments about expected quality as some cues may be perceived as being more relevant than others $[15,16]$. However, past research revealed that consumers may differ in their dependence on both intrinsic and extrinsic cues as well as in their capability to correctly measure product cues accurately [17-19]. For this reason, it is important to understand the respective influence of quality cues in consumers' perception of offal quality appraisal to enhance attributes most likely to influence consumers' opinions. It is well known that offal tends to have an undesirable brand image before now and this may affect the emotions and consumers behavior [8]. This negative approach toward offal meat production and consumption could be weakly exhibited in the behavior and perception of the consumers. Typically, the attitudes and belief of the consumer on offal may depend on the acceptance of the product and their features [7]. Presently, offal products are now relevant in our meals and diets regardless of the earlier global negative outlooks towards them [8]. This is because consumers have passed the stage of vague ideas in which some confidence is placed on offal as an odd animal product.

Normally, consumers' perception on carcass meat quality is directly related to the visual appearance (color, fat content, marbling, and drip loss) and their preferred point of purchase [20]. The visual appearance of meat related products has a close interaction with the meat color, therefore indicates a systemic relationship. In addition, meat color is associated with the diverse forms of the sarcoplasmic protein myoglobin [21] and it is also considered as the key fresh meat features that consumers look for before purchase [22]. In beef, for instance, dark colored meat could face acceptability problem when customers are actually looking for a bright red meat at the point of purchase $[10,23]$. The freshness of meat is therefore related to the bright color of carcass meat for predicting meat quality. Consumers normally believe that freshness of meat in a sanitized purchase outlet provides assurance for safer meat [24]. However, some of the consumers in South Africa are too casual about meat safety, hence the purchase of meat and offal from street vendors which may be susceptible to health concerns [25].

Acceptability of meat and offal meat may be influenced by tradition, norms, and custom of a particular society. For this reason, assessment of quality cues could take place within the thoughts of consumer and altered by individual preference, thus judgments on meat quality vary from persons through societies and cultures [16]. As a result of this, preferences have been observed to vary within the same region and outside different regions [26]. Therefore, Steenkamp [15] concluded that whenever a quality assessment is carried out by any consumer, it is done and established on their past accumulated knowledge and information about the product.

Several studies on consumers' perception of fresh meat quality, the perception of consumers on the quality of mutton, factors associated with perceived beef quality, consumer perception and the role in the meat industry have been published $[6,27-30]$ but those studies did not consider offal meat. 
However, to the best of our knowledge, limited studies have focused on consumers' perception of offal meat consumption. In South Africa, however, there are insufficient data on consumer preference for offal meat consumption and the effects in the offal supply chain. It is therefore important to understand the factors influencing consumer actions when purchasing offal meat and their preferred outlet for such a purchase. This study, therefore, sought to identify factors that were more important to the consumer in offal consumption and purchase in Amathole District of South Africa.

\section{Materials and Methods}

\subsection{Study Site}

The Amathole District Municipality is the third largest of the seven Districts in the Eastern Cape Province in terms of population after O.R Tambo and Nelson Mandela bay Metropolitan areas in South Africa. It has a population of about 898,000 people, of which $53.03 \%$ and $46.97 \%$ are females and males, respectively. Majority of the population $(99.66 \%)$ are black. About $31 \%(281,000)$ of the population is over 40 years. The District is situated in the central part of the Eastern Cape Province [31]. It spans along the Sunshine Coast from the Fish River Mouth and alongside the Eastern Seaboard along the Wild Coast. It is bordered to the north by the Amathole Mountain Range. Amathole District Municipality is comprised of six local municipalities: Mbhashe, Mnquma, Great Kei, Amahlathi, Ngqushwa, and Raymond Mhlaba. The study was conducted in three different municipalities in the Amathole District of Eastern Cape Province of South Africa using random sampling. The selected municipalities were Mbhashe Municipality (Butterworth and Kentani), Raymond Mhlaba Municipality (Alice and Fort Beaufort) and Ngqushwa Municipality (Peddie and Hamburg).

\subsection{Selection of Respondents}

A total of 202 consumers from Amathole Districts in Eastern Cape Province from three randomly selected municipalities (Mbhashe, Raymond Mhlaba, and Ngqushwa municipalities) were sampled from a total of six towns in the municipalities. Consumers were randomly selected by selecting members of the community who could have basic knowledge and give better information about offal consumption. The participants were interviewed in their shops, schools, butcheries, parks, garages and those that were close to the shopping areas. The key quality indicators such as the color of offal, packaging, fatness, freshness, visual display, and consumption pattern (flavor, tenderness, and juiciness) which point toward the acceptability and preferred offal meat were included in the interview.

\subsection{Data Collection}

For the purpose of this study, a structured questionnaire was prepared, pre-tested and used to interview the consumers. Part of the questionnaire was translated into the vernacular (Xhosa) language for simplicity of administration to those who do not understand key terms in the questionnaire and where the use of English language was poor. The respondents were asked to complete a self-administered questionnaire while interpretation was done for some of the respondents. Patterns from similar recent studies on individual contributing factor on offal meat preference based on their demographic characteristics [32,33] were used. Demographic information such as educational status, gender, monthly income, age, and family size was included (Table 1). The consumers also answered questions pertaining to offal meat demanded in the last three months, preferred offal meat and preferred purchase-point (butcher, supermarket, and others), in line with Verbeke et al. [34]. With respect to approach, consumers were asked to indicate which factors influence their demand for offal meat, precisely for purpose of nutritional value, health reasons, cheapness (price) and availability [7]. The questionnaire further included eleven attributes on a five-point Likert scale to determine consumers' knowledge on the offal meat quality attributes by visual assessment (color of offal, packaging, fatness, freshness, and visual display) and consumption pattern (flavor, tenderness, 
and juiciness) but were all measured on a descriptive scale. Each volunteered respondent who participated in the interview was requested to sign a written consent letter.

Table 1. Demographic characteristic of consumers interviewed in Amathole District.

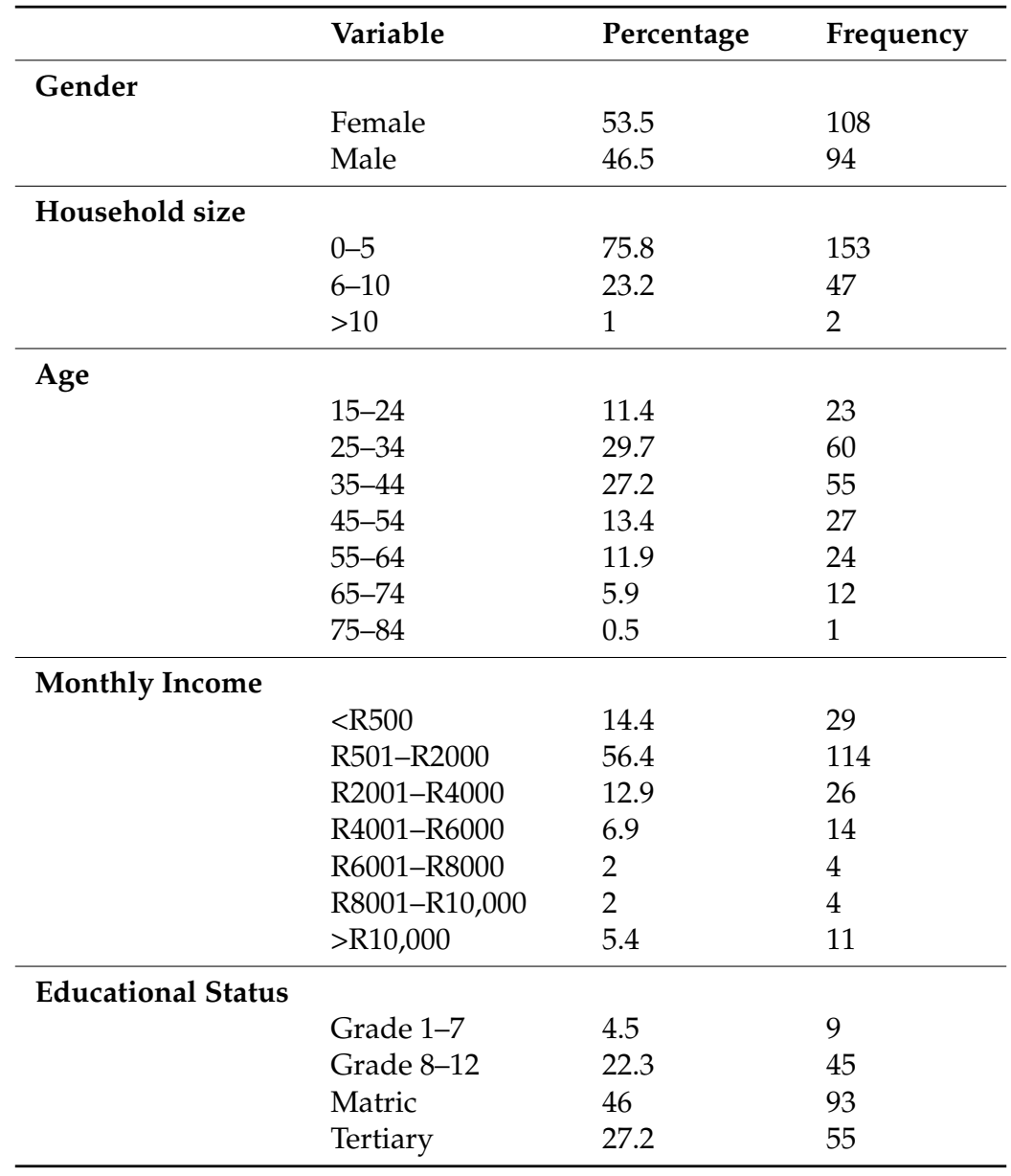

\subsection{Statistical Analyses}

Data generated were entered in Microsoft Excel and were summarized as frequencies of respondent profiles on consumers' perception. Descriptive statistics was used to determine associations between age, income, educational status, and other factors influencing offal consumption using SPSS version 20 (SPSS 20, IBM, Armonk, NY, USA) for the analysis. Chi-square statistics were used to test the association between variables at a 95\% confidence interval. $p<0.05$ was considered as statistically significant.

\section{Results and Discussion}

\subsection{Consumer Demography and Attributes}

In Table 1, the total number of 202 respondents who were interviewed, the majority of the respondents were females (53.3\%) while males represented $46.5 \%$ of the research sample. Furthermore, it was observed that most of the respondents had formal education. However, the findings showed that $4.5 \%$ of the respondents had the lowest form of education and had stopped at elementary grade. Meanwhile, $46 \%$ had gone through matriculation and $27.2 \%$ possessed at least an undergraduate degree (Table 1). The majority of the respondents were either working within the governmental departments, private sector or owned their personal business earning from R500 to more than R10,000 on monthly 
basis. In Table 1, the most prevailing earned income among the respondents was R501-R2000 (56.4\%) while the least represented incomes were R8001-R10000 (2\%) and R6001-R8000 (2\%), respectively.

Correlation analysis was performed to establish the relationships between offal meat attributes and demography. The result showed that there was a significant relationship at $p$-value $0.026, p$-value $0.012, p$-value 0.020 and $p$-value 0.031 but a positive correlation between gender and color, packaging, tenderness and juiciness of the offal meat products (Table 2). This means that the color, packaging, tenderness, and juiciness of the offal meat products tend to vary from male to female at the point of purchase.

The estimated relationship between the education of the respondents and their perception about the smell of the offal was significant at $p$-value 0.025 but was weakly correlated. On the other hand, the level of education was significant at $p$-value 0.018 with a positive correlation with the visual display at the point of purchase. This shows that, as the level of education increases, consumers attach more credence to the visual display of the offal and this influences decision at purchase-points. Demography has been used to a great extent for interpreting consumers' purchasing behavior. However, Romano and Stefani [35] revealed that there is a narrow line between demographic variables and purchase decision. This is in agreement with the results obtained from this study where variables such as age, monthly income, family size, and gender were observed to be weak factors influencing consumers' purchase decision.

\subsection{Attributes and Consumers' Choice of Purchase-Point}

The findings from this study revealed that most of the respondents preferred sheep offal (83\%) as compared to cattle offal (33\%), although the percentage of those who preferred sheep and cattle offal $(86 \%)$ was the highest (Table 3). This result was in agreement with Walsh [36] who described that sheep offal is in more demand than cattle offal. Furthermore, the findings are similar to the recent study conducted in Ghana by Ayroe et al. [37] who reported a higher preference for both cattle and goat offal.

With respect to purchasing decisions, the interview focused on the preferred place of purchase, preferred offal, and offal meat products consumed in the last three months. When consumers were asked what type of offal meat products they like to eat and from which type of animal, it was observed that consumers were selective in the type of offal they consume, for example, liver (94.1\%), tripe $(78.2 \%)$ and intestine $(68.8 \%)$ were the most demanded products and consumed in the last three months (Figure 1). This showed that the percentage of consumers who eat certain types of offal products differ from one another. The preference shown in this study concur with Nonterah et al. [38] who reported that the most preferred offals are liver and stomach at the point of purchase. This same trend for the demand of liver, tripe, and intestine was seen among the respondents that prefer sheep offal $(37.6 \%, 32 \%$ and $31.2 \%$, respectively) and cattle offal $(15.3 \%, 12.5 \%$ and $8.9 \%$, respectively).

In general, it could be deduced that consumers explored all the retail outlets (butchery, supermarkets, and other retail outlets) for the purchase of offal meat. However, the majority of respondents preferred to buy offal meat from butchery (Figure 2). A greater percentage of respondents who purchased liver $(64.4 \%)$, heart $(42.6 \%)$, tongue $(40.1 \%)$, kidney (37.6\%) tripe $(59.4 \%)$, spleen $(34.7 \%)$, intestine (59.4\%), and lungs (37.6) did so in butcheries as compared to other outlets. This concurs with the recent study by Ayroe et al. [37] who reported that consumers purchased their favorite offal products mostly from the butcher shops.

Furthermore, the respondents were asked why they chose the butchery in preference to other selling or retail outlets. The respondents replied that the offal meat sold at butchery was fresher and cheaper. In addition, the respondents alluded to the fact that they preferred the butchery because the other types of offal meat were not readily accessible in other outlets as compared to the butchery. Moreover, it emerged that purchase of offal meat at the butchery also gave the consumers the opportunity to buy a combination of different offals as a single item otherwise called "combo" as compared to the supermarkets where the chances of purchasing in bulk are limited. Nevertheless, there were a few respondents who chose to buy fresh offal products occasionally from supermarkets and street traders. 
Table 2. The correlation coefficients between demographic and perception on eleven offal meat quality.

\begin{tabular}{|c|c|c|c|c|c|c|c|c|c|c|c|}
\hline Demography & Color & Leanness & Presence of Fat & Smell & Freshness & Flavor & Packaging & Price & Tenderness & Juiciness & Visual Display \\
\hline Age & 0.227 & 0.292 & -0.660 & 0.310 & -0.231 & -0.899 & -0.029 * & 0.702 & -0.867 & -0.952 & 0.889 \\
\hline Gender & $0.026^{*}$ & 0.668 & 0.474 & -0.392 & -0.820 & 0.750 & $0.012 *$ & 0.248 & 0.020 * & 0.031 * & -0.149 \\
\hline Education & 0.876 & -0.175 & 0.102 & $-0.03 *$ & -0.982 & -0.460 & 0.174 & 0.414 & 0.573 & 0.061 & $0.018 *$ \\
\hline Income & 0.088 & -0.145 & 0.523 & -0.187 & -0.904 & -0.816 & 0.774 & 0.228 & -0.107 & 0.145 & 0.084 \\
\hline H/Size & -0.397 & 0.865 & $0.029 *$ & 0.234 & -0.173 & -0.933 & -0.242 & -0.87 & -0.459 & 0.860 & 0.291 \\
\hline
\end{tabular}

Table 3. Distribution of specific preferred offal type as indicated by consumers.

\begin{tabular}{ccc}
\hline Offal Type & Percentage & Frequency \\
\hline Sheep & 41.1 & 83 \\
Cattle & 16.3 & 33 \\
Sheep and Cattle & 42.6 & 86 \\
\hline
\end{tabular}


The interviews were similarly focused on visual and quality assessment of offal meat (color, packaging, visual display, fat inclusion, freshness, and price). Assessment of visual appearance was derived from previous work by De Andrade [39] and measured on descriptive scales using a five-point Likert scale (disagree to strongly agree). The variables which best described the quality of offal meat with respect to their importance in the consumers' decision to purchase offal are shown in Figure 3. The results showed that respondents who purchased fresh offal products from retail outlets cited freshness as the major factor which assisted them to distinguish the quality of the meat offered in any retail outlets. Consumers' perception on the freshness of offal is, therefore, very important at any selling point. These results commensurate with Verbeke et al. [33] who reported that freshness is the most effective factor that influences consumers' decision to purchase fresh meat. Jabbar [40] also concluded in his study that freshness and price among other quality attributes play a vital role for consumers to make their decision at the point of purchase.

The price of offal was also observed and presented by consumers as one of the major attributes of quality for offal meat when compared to other types of meat, which are more expensive. Most of the respondents felt the price was a strong factor which contributed to whether to eat or purchase offals. Some respondents acknowledged that offal products sold at the butcher shop were relatively cheaper and the quantity was high as compared to the supermarkets. The findings also indicated that the more the consumers ate any offal meat products the higher the demand for the products in the last three months. A likely reason could be as a result of the price of offal, which was found to be considerably cheaper at the butchery than supermarkets. This is in agreement with the law of demand which states that the quantity of goods leads to a rise in demand as the price falls, and vice versa. Offal meat products still account for an insignificant part of meat markets and their demand is still far behind the production potential of resources available [41].

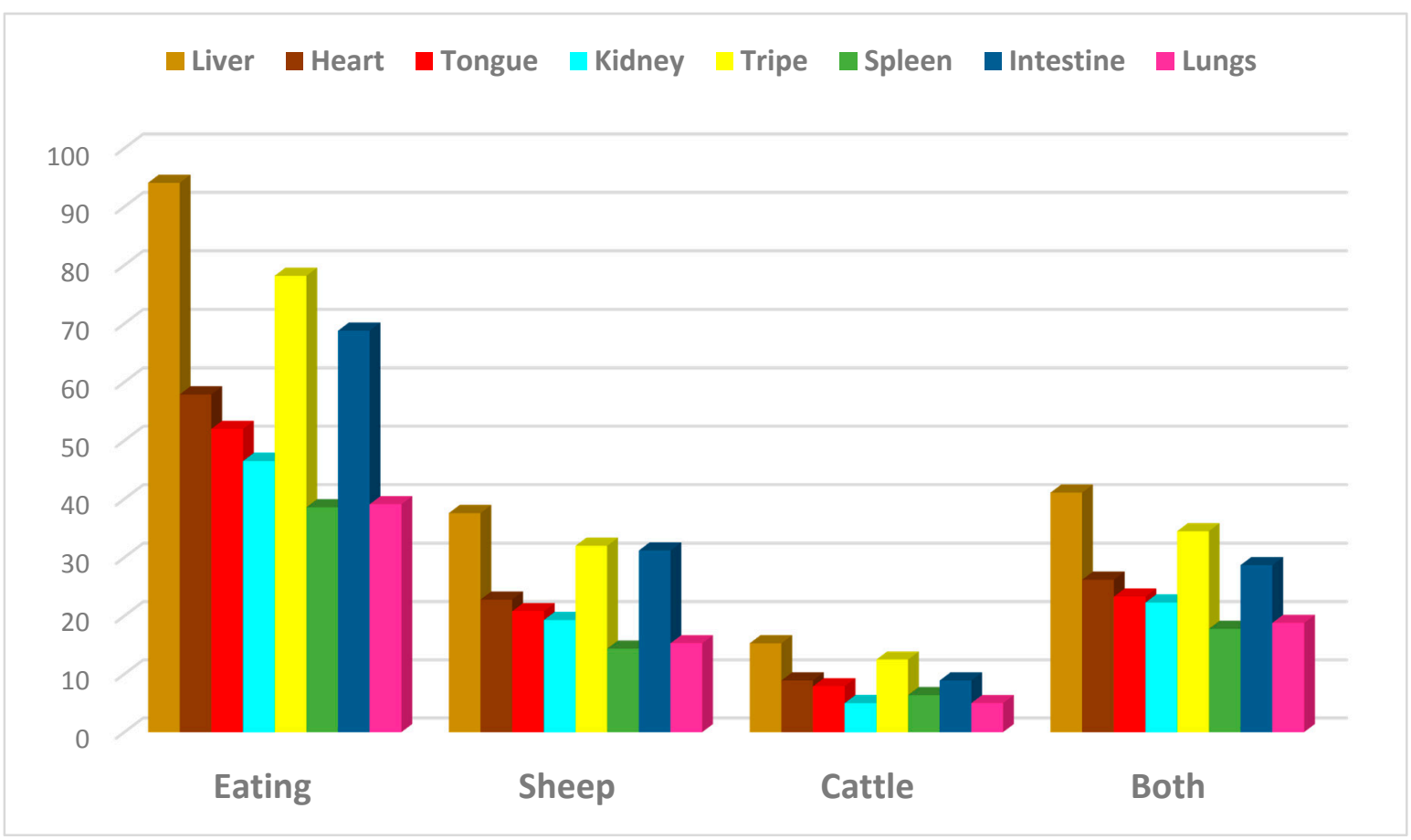

Figure 1. Distribution percentage of offal meat demanded and preferred offal type. 


\section{Distribution percentage of offal meat purchase-points}

$\square$ Liver $\square$ Heart $\square$ Tongue $\square$ Kidney $\square$ Tripe $\square$ Spleen Intestine $\square$ Lungs

70

60

50

40

30

20

10

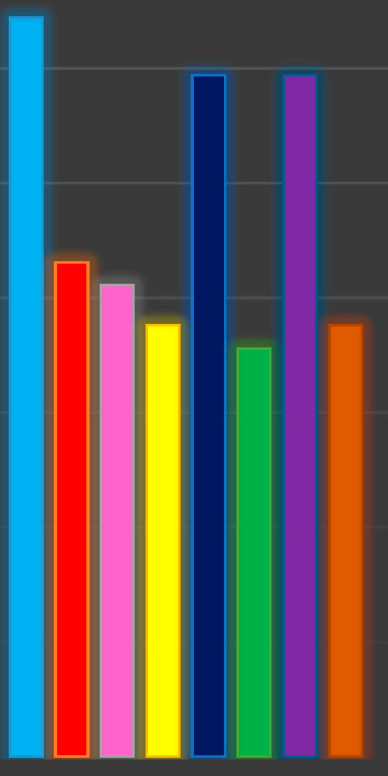

Butchery

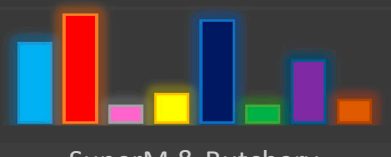

SuperM \& Butchery

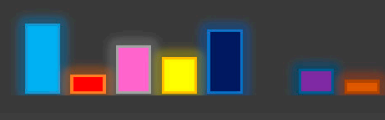

others

Figure 2. Distribution percentage of offal meat purchase-points. 


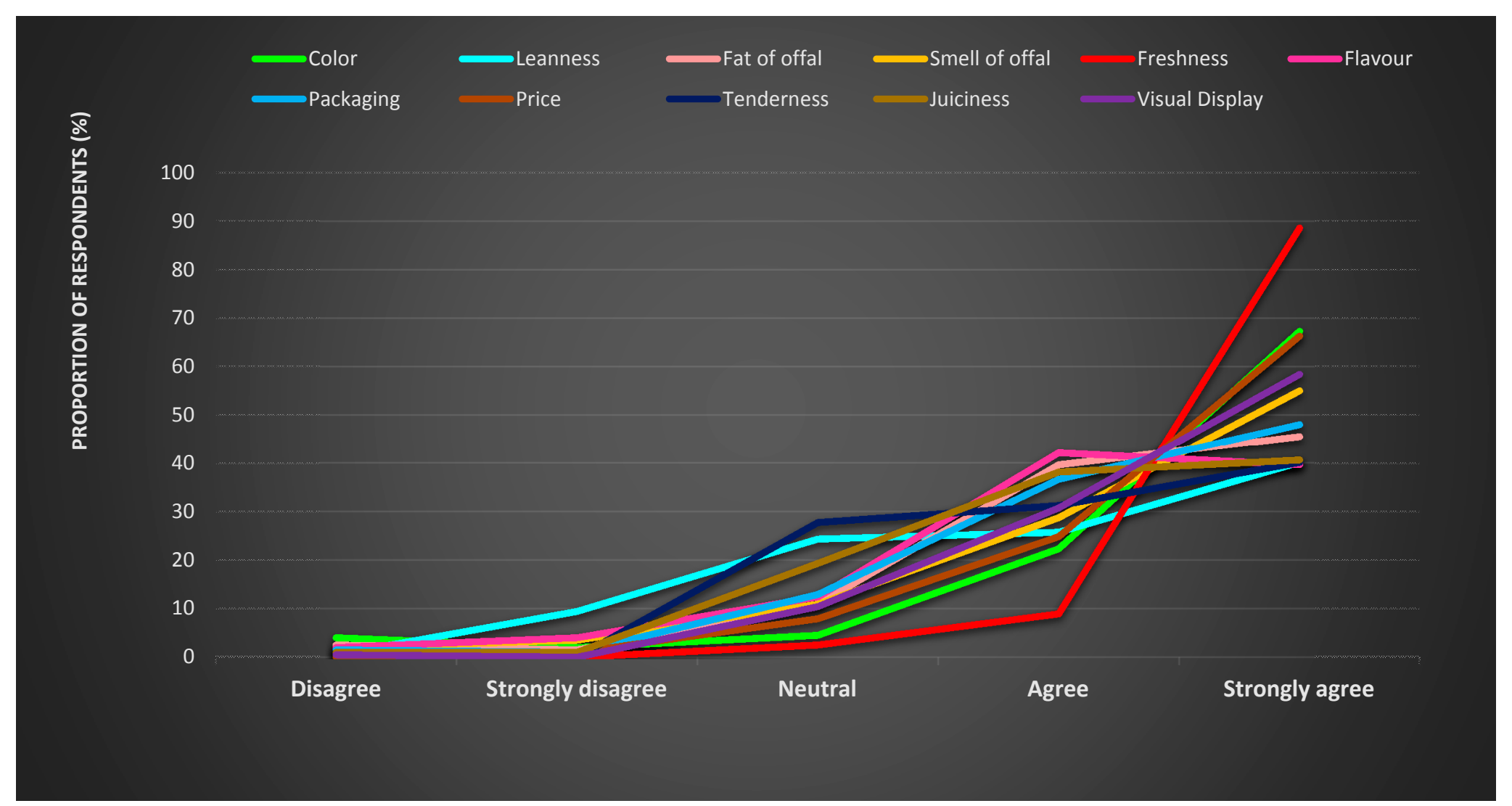

Figure 3. Ranking of offal meat attributes influencing consumers' purchase. 
It was further observed that the highest point of preference when offal meat is to be purchased is the price of offals, i.e., whether they are cheap or not. This implies that the price, availability and nutritional value of the product in a regular succession are critical (Figure 4). These three factors form the major factors influencing offal demand. The price of liver $(43.6 \%)$, heart $(30.7 \%)$, tripe $(43.1 \%)$, spleen (18.8\%), intestine (40.6\%); and availability of liver (41.1\%), heart (28.7\%), tongue (20.8\%), kidney $(22.3 \%)$. tripe $(39.1 \%)$, spleen $(15.3 \%)$, intestine $(39.1 \%)$, and lungs $(22.85)$ emerged as being very important for the demand of offals. The consumers also revealed that they have nutritional knowledge of the offal meat products before making their purchase. Meanwhile, health reasons emerged as the least factor that the consumers considered at the point of purchase (Figure 4). This, however, contradicts the observation of Jabbar [40] that price is the least important quality factor relative to the income of the consumer. In as much as Jabbar's [40] observation may be true for purchases of beef, it does not apply to offal meat.

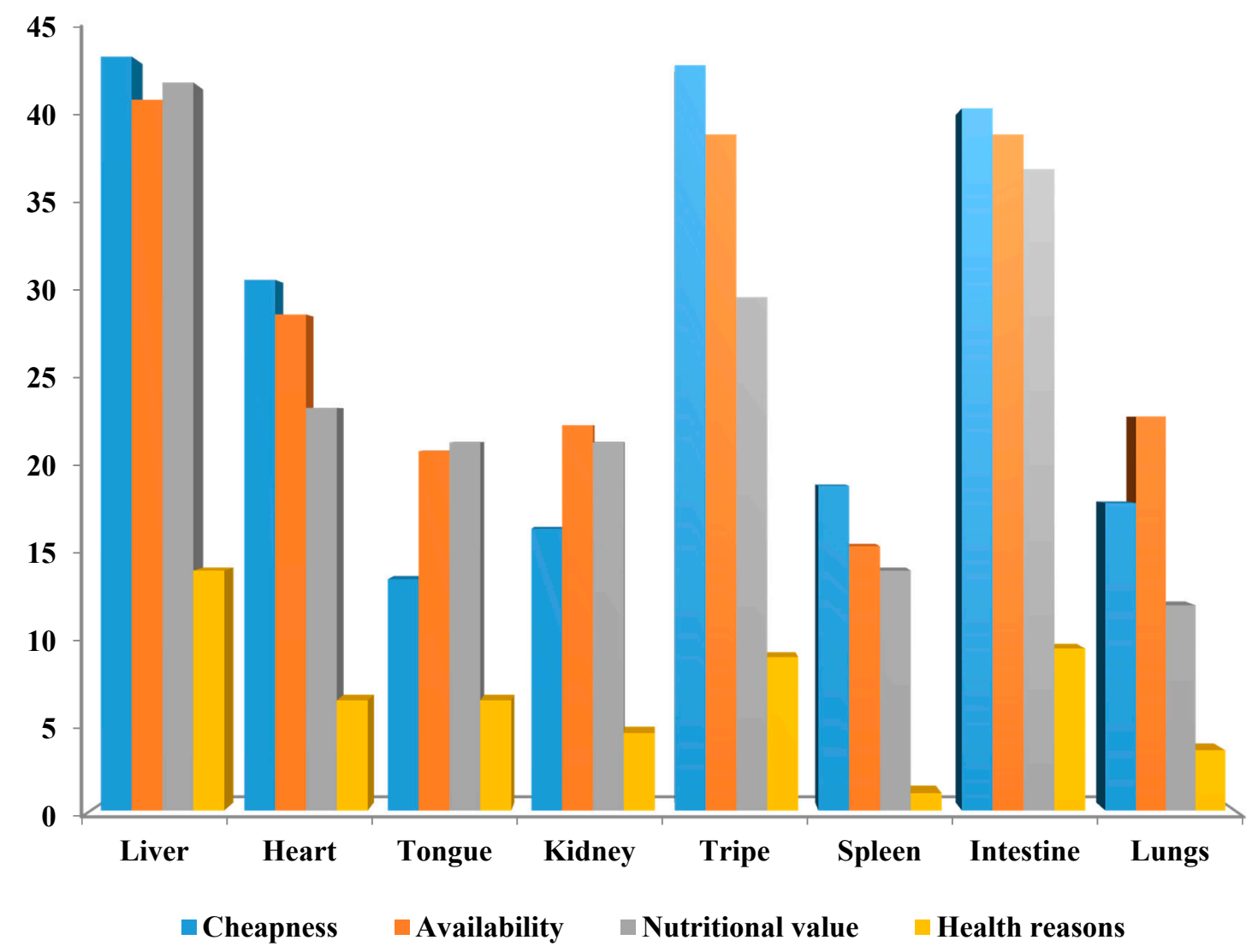

Figure 4. Factors influencing the demand for offal meat.

\section{Conclusions}

From the respondents who participated in this survey, it was revealed that consumers had a higher preference for offal meat products from the butchery because it was cheaper, readily available and fresher. Most of the consumers strongly agreed that the meat quality attributes influenced their decision during the purchase of offal meat. However, variables such as the color, price, freshness, visual display and packaging of the offal were ranked as the most influential in making choice to purchase in comparison to other factors such tenderness and fat content. The point of purchase, however, remains a prominent factor among other factors that could influence decision making for any consumer. When it comes to offal meat, the results showed that the majority of consumers purchased more liver, intestine, and tripe because they are often sold in a combo at the butchery. However, some consumers may expect distinct or special quality attributes based on their individual experience. It is 
also known that consumers' mental attitude and insight about acceptable quality attributes could be attached to their socioeconomic status and personal preference.

In addition, the findings of the study inferred that nearly all types of offal meat are consumed in Amathole district, especially liver, kidney, tripe, intestines, heart, and tongue, while kidney and spleen were mentioned by some respondents to be mostly consumed by men. The foremost factors influencing offal consumption comprised of availability of offal meat, price, freshness, nutritional value, and health reasons. These offal meat products are nutritionally appropriate for different age groups, especially children and women. The perception of consumers on offal meat consumption is similar to the indicators and factors that are considered when the consumer is about to purchase red meat, which suggests the results are important for developing effective growth strategies to promote the offal meat market in the municipality. In addition, this means that municipalities need to re-orientate and enlighten people about the nutritional benefits, as well as food safety and health implications of offal consumption.

Author Contributions: B.O.A. and V.M. conceptualized and designed the work. B.O.A. was accountable for conducting research and drafting the manuscript. A.B.F. was responsible for statistical analysis. A.C. and A.B.F. visualized and proofread the manuscript. The authors of this manuscript approved the content of this manuscript.

Funding: This research received no external funding.

Acknowledgments: The authors are grateful to the Govan Mbeki Research and Development Centre, University of Fort Hare (GRMDC, UFH) for their support during this research.

Conflicts of Interest: The authors declare no conflict of interest.

\section{References}

1. Powell, D. Mad cow disease and the stigmatization of British beef. In Risk, Media, and Stigma: Understanding Public Challenges to Modern Science and Technology; Earthscan Publication Ltd.: London, UK; Sterling, VA, USA, 2001; pp. 219-228.

2. Fox, J.A.; Peterson, H.H. Bovine Spongiform Encephalopathy (BSE): Risks and Implications for the United States. 2002. Available online: http:/ / ageconsearch.umn.edu/bitstream/19061/1/cp02fo02.pdf (accessed on 17 June 2018).

3. Selmane, D.; Christophe, V.; Gholamreza, D. Extraction of proteins from slaughterhouse by-products: Influence of operating conditions on functional properties. Meat Sci. 2008, 79, 640-647. [CrossRef] [PubMed]

4. Alao, B.O.; Falowo, A.B.; Chulayo, A.; Muchenje, V. The potential of animal by-products in food systems: Production, prospects and challenges. Sustainability 2017, 9, 1089. [CrossRef]

5. Fayemi, P.O.; Muchenje, V. Maternal slaughter at abattoirs: History, causes, cases and the meat industry. SpringerPlus 2013, 2, 125. [CrossRef] [PubMed]

6. Xazela, N.M.; Hugo, A.; Marume, U.; Muchenje, V. Perceptions of Rural Consumers on the Aspects of Meat Quality and Health Implications Associated with Meat Consumption. Sustainability 2017, 9, 830. [CrossRef]

7. Grunert, K.G.; Bredahl, L.; Brunsø, K. Consumer perception of meat quality and implications for product development in the meat sector-A review. Meat Sci. 2004, 66, 259-272. [CrossRef]

8. Font-i-Furnols, M.; Luis, G. Consumer preference, behavior and perception about meat and meat products: An overview. Meat Sci. 2014, 98, 361-371. [CrossRef] [PubMed]

9. Grunert, K.G. Food quality and safety: Consumer perception and demand. Eur. Rev. Agric. Econ. 2005, 32, 369-391. [CrossRef]

10. Acebrón, L.B.; Domingo, C.D. The importance of intrinsic and extrinsic cues to expected and experienced quality: An empirical application for beef. Food Qual. Prefer. 2000, 11, 229-238. [CrossRef]

11. Richardson, N.J. UK consumer perceptions of meat. Proc. Nutr. Soc. 1994, 53, 281-287. [CrossRef] [PubMed]

12. Steenkamp, J.B.E.M.; van Trijp, H.C.M. Quality guidance: A consumer-based approach to food quality improvement using partial least squares. Eur. Rev. Agric Econ. 1996, 23, 195-215. [CrossRef]

13. Bernués, A.; Ana, O.; Kate, C. Extrinsic attributes of red meat as indicators of quality in Europe: An application for market segmentation. Food Qual. Prefer. 2003, 14, 265-276. [CrossRef]

14. Hoffmann, R. Country of origin-A consumer perception perspective of fresh meat. Br. Food J. 2000, 102, 211-229. [CrossRef] 
15. Steenkamp, J.-B.E.M. Conceptual model of the quality perception process. J. Bus. Res. 1990, 21, 309-333. [CrossRef]

16. Henchion, M.; McCarthy, M.; Resconi, V.C.; Troy, D. Meat consumption: Trends and quality matters. Meat Sci. 2014, 98, 561-568. [CrossRef] [PubMed]

17. Salleh, M.M.; Ali, S.M.; Harun, E.H.; Jalil, M.A.; Shaharudin, M.R. Consumer's Perception and Purchase Intentions Towards Organic Food Products: Exploring Attitude Among Academician/La Perception Et L'intention De Rachat Des Consommateurs Envers Les Produits Alimentaires Biologiques: Études Sur L'attitude Des Universitaires. Can. Soc. Sci. 2010, 6, 119-129.

18. Kardes, F.R.; John, K.; JeenSu, L. Consumer expertise and the perceived diagnosticity of inference. Adv. Consum. Res. 2001, 19, 409-410.

19. Roberta, V.; Quester, P.; Karunaratna, A. The role of intrinsic (sensory) cues and the extrinsic cues of country of origin and price on food product evaluation. In Proceedings of the 3rd International Wine Business and Marketing Research Conference, Montpellier, France, 6-8 July 2006.

20. Banović, M.; Klaus, G.; Grunert, M.; Madalena, B.; Magda, A.F. Beef quality perception at the point of purchase: A study from Portugal. Food Qual. Prefer. 2009, 20, 335-342. [CrossRef]

21. Mancini, R.A. Meat color. In Improving the Sensory and Nutritional Quality of Fresh Meat; Kerry, J.R., Ledward, D., Eds.; CRC Press: Boca Raton, FL, USA; Woodhead Publishing Limited: Cambridge, UK, 2009; pp. 89-110.

22. Gracia, A.; de-Magistris, T. Preferences for lamb meat: A choice experiment for Spanish consumers. Meat Sci. 2013, 95, 396-402. [CrossRef] [PubMed]

23. Realini, C.E.; Kallas, Z.; Pérez-Juan, M.; Gómez, I.; Olleta, J.L.; Beriain, M.J.; Albertí, P.; Sañudo, C. Relative importance of cues underlying Spanish consumers' beef choice and segmentation, and consumer liking of beef enriched with n-3 and CLA fatty acids. Food Qual. Prefer. 2014, 33, 74-85. [CrossRef]

24. Chamhuri, N.; Peter, J.B. Exploring the factors influencing consumers' choice of retail store when purchasing fresh meat in Malaysia. Int. Food Agribus. Manag. Rev. 2013, 16, 99-122.

25. Labuschagne, A.; Louw, A.; Ndanga, L. A Consumer-Orientated Study of the South African Beef Value Chain. 2010. Available online: https://ageconsearch.umn.edu/bitstream/113788/2/199.\%20Beef\%20supply\% 20chain\%20in\%20South\%20Africa.pdf (accessed on 5 March 2018).

26. Prescott, J.; Young, O.; Zhang, S.; Cummings, T. Effects of added flavour principles on liking and familiarity of a sheepmeat product: A comparison of Singaporean and New Zealand consumers. Food Qual. Prefer. 2004, 15, 187-194. [CrossRef]

27. Mannion, M.A.; Cowan, C.; Gannon, M. Factors associated with perceived quality influencing beef consumption behaviour in Ireland. Br. Food J. 2000, 102, 195-210. [CrossRef]

28. Becker, T.; Benner, E.; Glitsch, K. Consumer perception of fresh meat quality in Germany. Br. Food J. 2000, 102, 246-266. [CrossRef]

29. Troy, D.J.; Kerry, J.P. Consumer perception and the role of science in the meat industry. Meat Sci. 2010, 86, 214-226. [CrossRef] [PubMed]

30. Rani, Z.T.; Hugo, A.; Muchenje, V. Perceptions of rural consumers on the quality of mutton in the Eastern Cape Province, South Africa. Sci. Res. Essays 2013, 21, 921-931.

31. Integrated Development Plan (IDP). Amathole District Municipality IDP Review 2017-2016. Available online: www.amathole.gov.za/attachments/article/526/1617\%20final\%20idp.pdf (accessed on 7 September 2018).

32. Russell, C.G.; Cox, D.N. Understanding middle-aged consumers' perceptions of meat using repertory grid methodology. Food Qual. Prefer. 2004, 15, 317-329. [CrossRef]

33. Verbeke, W.; Isabelle, V. Profile and effects of consumer involvement in fresh meat. Meat Sci. 2004, 67, 159-168. [CrossRef] [PubMed]

34. Verbeke, W.; Ronald, W.W.; Jacques, V. Probit analysis of fresh meat consumption in Belgium: Exploring BSE and television communication impact. Agribusiness 2000, 16, 215-234. [CrossRef]

35. Romano, D.; Stefani, G. The TRUST project: Summary of main findings. In How Safe is Eating Chicken? A Study on the Impact of Trust and Food Risk Communication on Consumer Behaviour in the European Union; Firenze University Press: Firenze, Italy, 2006; pp. 143-150. 
36. Walsh, C. The Use of Animal By-Products: The Improving Opportunities to Add Value to the Beef and Sheep Slaughtering Sectors. EBLEX, 2014; pp. 25-49. Available online: https://beefandlamb.ahdb.org.uk/ wp-content/uploads/2016/07/74318-5th-Quarter-Use-and-Flow-Final-Report-130514.pdf (accessed on 23 March 2018).

37. Ayroe, F.; Emikpe, B.O.; Asiamah, E.; Dankwa, K.O. Consumers' preference and associated pathology observed in cattle and goat offals in Kumasi, Ghana. Afr. J. Infect. Dis. 2016, 10, 127-133.

38. Nonterah, E.W.; Nyarko, T.A.; Emikpe, B.O.; Asare, D.A. Consumer preference for swine offals and its health implications in Kumasi, Ghana. Anim. Res. Int. 2016, 12, 2305-2310.

39. De Andrade, J.C.; Nalério, E.S.; Giongo, C.; de Barcellos, M.D.; Ares, G.; Deliza, R. Consumer perception ofdry-cured sheep meat products: Influence of process parameters under different evoked contexts. Meat Sci. 2017, 130, 30-37. [CrossRef] [PubMed]

40. Jabbar, M.A. Assessing Consumer Preferences for Quality and Safety Attributes of Food in the Absence of Official Standards: The Case of Beef in Ethiopia. In Proceedings of the International Association of Agricultural Economics Conference, Beijing, China, 16-22 August 2009; Available online: https: / /ageconsearch.umn.edu/bitstream/50120/2/IAAEpaperRef40.pdf (accessed on 7 August 2018).

41. Liu, X.; Mack, K.N.; Mohammed, I. Analyzing Consumer's Calculation Factors in the Purchase Decision of Goat Meat. J. Food Distrib. Res. 2007, 38, 196-202.

(C) 2018 by the authors. Licensee MDPI, Basel, Switzerland. This article is an open access article distributed under the terms and conditions of the Creative Commons Attribution (CC BY) license (http://creativecommons.org/licenses/by/4.0/). 